\title{
SISTEM PENGGEMBALAAN SEBAGAI ALTERNATIF PETERNAKAN SAPI POTONG YANG EFEKTIF DAN EFISIEN
}

\author{
Yoselanda Marta \\ BPTUHPT Padang Mengatas \\ email : yoselandamarta@yahoo.co.id
}

\begin{abstract}
ABSTRAK
Pemeliharaan ternak khususnya sapi sampai saat ini masih berhadapan dengan permasalahan penyediaan pakan hijauan yang berkesinambungan. Hampir 70\% biaya produksi dan pemeliharaan sapi pengeluarannya bersumber dari pakan. Efisensi tenaga kerja menjadi salah satu permasalahan yang belum terselesaikan dengan baik. Berbagai metoda dikembangkan untuk mencari solusi yang diharapkan mampu untuk menyelesaikan permasalahan-permasalahan yang muncul. Terobosan -terobasan yang dilakukan unyuk menghadirkan solusi terus dikembangkan. Salah satunya adalah dengan dilakukannya sistem penggembalaan dengan metoda pastura. Dengan sistem ini di harapkan mampu untuk menyelesaikan permasalahan-permasalahan. Metoda ini dinilai tepat untuk diterapkan karena mampu meminimalisir biaya pakan dan mengefisienkan tenaga kerja.
\end{abstract}

Kata kunci : pakan, tenaga kerja, biaya

\section{ABSTRACT}

Raising of livestock, especially cattle is still faced with problems of a continuous supply of green feed. Nearly $70 \%$ of production costs and maintenance expenditure sourced from cattle feed. Labor efficiency being one of the problems that have not been resolved. Various methods were developed to find a solution that will be able to resolve problems that arise. Breakthroughs were made to bring the solution to be developed. One is to do with the method of pasture grazing system. With this system is expected able to resolve the issues. This method is considered appropriate to be applied as to minimize feed costs and streamline workforce.

Keynote : feed, workforce, cost value

\section{PENDAHULUAN}

Pakan hijauan merupakan salah satu faktor penting dalam menentukan tingkat produksi dan produktivitas ternak sapi sehingga penyediaan pakan yang cukup sangat menentukan keberhasilan suatu usaha peternakan. Pemberian pakan hijauan oleh peternak sangat tergantung pada kondisi sosial ekonomi, motivasi dan tujuan beternak itu sendiri. Sampai saat ini beternak sapi sebagian besar masih merupakan usaha sambilan bagi peternak dimana peternak tidak mengalokasikan biaya khusus untuk pakan, sehingga pakan hijauan yang diberikan pada ternak tidak mencukupi sehingga performance produksi tidak seperti yang diharapkan. Penyediaan pakan hijauan sangat tergantung dengan tersedianya bibit yang mencukupi baik kuantitas maupun kualitas.

Salah satu kendala yang dihadapi dalam penyediaan hijauan pakan ternak sapi adalah tidak tersedianya bibit hijauan unggul yang mudah diperoleh petani karena kurangnya pengetahuan serta penyuluhan dari institusi yang khusus menangani pakan hijauan ternak, sehingga hijauan pakan ternak yang dipelihara petani masih sangat terbatas dan kualitas masih sangat rendah. Bertitik tolak dari hal diatas dan mengingat pentingnya peranan pakan hijauan dalam usaha pemeliharaan ternak sapi serta tingginya potensi pengembangan usaha ternak rakyat maka diperlukan langkah-langkah terobosan dalam penyediaan pakan hijauan dengan mengoptimalkan fungsi lahan dan pengetahuan peternak tentang tata cara pengelolaan padang penggembalaan baik sehingga diharapkan penyediaan pakan hijauan terpenuhi.

\section{DASAR PEMIKIRAN PADANG PENGGEMBALAAN}

\section{Definisi Padang Penggembalaan}

Padang penggembalaan adalah suatu daerah padangan di mana tumbuh tanaman makanan ternak yang tersedia bagi ternak yang dapat menyenggutnya menurut kebutuhannya dalam waktu singkat (Anonimus, 1990). Padang penggembalaan tersebut bisa terdiri dari rumput atau leguminosa. Tetapi suatu padang rumput yang baik ekonomis adalah yang terdiri dari campuran rumput dan leguminosa (Anonimus, 1995).

\section{Macam padang penggembalaan}

\section{Padang Penggembalaan Alam}

Padangan yang terdiri dari tanaman dominan yang berupa rumput perennial, sedikit atau tidak ada sama sekali belukar gulma (weed), tidak ada pohon, sering disebut padang penggembalaan permanen, tidak ada campur tangan manusia terhadap susunan floranya, manusia hanya mengawasi ternak yang digembalakan (Reksohadiprodjo, 1985). 


\section{Padang Penggembalaan Alam yang Sudah Ditingkatkan}

Spesies-spesies hijauan makanan ternak dalam padangan belum ditanam oleh manusia, tetapi manusia telah mengubah komposisi botaninya sehingga didapat spesies hijauan yang produktif dan menguntungkan dengan jalan mengatur pemotongan (defoliasi) (Reksohadiprodjo, 1985).

\section{Padang Penggembalaan Buatan}

Tanaman makanan ternak dalam padangan telah ditanam, disebar dan dikembangkan oleh manusia. Padangan dapat menjadi padangan permanen atau diseling dengan tanaman pertanian (Reksohadiprodjo, 1985).

\section{Padang Penggembalaan dengan Irigasi.}

Padangan biasanya terdapat di daerah sepanjang sungai atau dekat sumber air. Penggembalaan dijalankan setelah padangan menerima pengairan selama 2 sampai 4 hari (Reksohadiprodjo, 1985).

\section{Fungsi padang penggembalaan}

Fungsi padang penggembalaan adalah untuk menyediakan bahan makanan bagi hewan yang paling murah, karena hanya membutuhkan tenaga kerja sedikit, sedangkan ternak menyenggut sendiri makanannya di padang penggembalaan. Rumput yang ada di dalamnya dapat memperbaiki kesuburan tanah. Hal ini disebabkan pengaruh tanaman rumput pada tanah, rumput yang dimakan oleh ternak dikembalikan ke padang penggembalaan sebagai kotoran yang menyuburkan dan menstabilkan produktivitas dari tanah itu sendiri (Anonimus, 1990).

\section{Syarat padang penggembalaan}

Syarat padang penggembalan yang baik adalah produksi hijauan tinggi dan kualitasnya baik, persistensi biasa ditanam dengan tanaman yang lain yang mudah dikembangbiakkan (Reksohadiprojo, 1985). Pastura yang baik nilai cernanya adalah pastura yang tinggi canopinya yaitu 25 sampai $30 \mathrm{~cm}$ setelah dipotong. Padang penggembalaan yang baik mempunyai komposisi botani 50\% rumput dan 50\% legum. Besarnya kadar air dan bahan kering yang harus dimiliki oleh suatu padangan adalah 70 sampai $80 \%$ untuk kadar air dan bahan keringnya 20 sampai 30\%. Hijauan pastura membutuhkan periode istirahat untuk tumbuh kembali 16 sampai 36 hari setelah dipotong. Oleh sebab itu, pastura digembalai secara rotasi untuk memberi kesempatan bagi hijauan untuk tumbuh kembali, dan juga untuk mencegah infeksi cacing. Untuk pastura alam sebaiknya dibakar secara periodik, karena hal ini dapat memusnahkan rumput yang tidak palatabel dan kering, serta untuk merangsang pertumbuhan tanaman muda yang lebih tinggi nilai gizinya dan lebih disukai ternak (Reksohadiprodjo dan Utomo, 1983).

\section{Persiapan dan perbaikan padang penggemba- laan}

Menurut Anonimus (1990), ada beberapa tahapan dalam permbuatan padang penggembalaan, yaitu meliputi :

\section{Pemilihan lokasi.}

Hal-hal yang perlu dipertimbangkan dari segi kultur teknis dalam pemilihan lokasi untuk padang penggembalaan adalah sumber air, kesuburan tanah, topografi, dan komunikasi.

\section{Bahan penanaman.}

Mempergunakan bahan penanaman yaitu bibit atau benih yang baik, sehingga efisien waktu, tenaga dan biaya.

\section{Waktu pengolahan tanah dan penanaman}

Pada keadaan irigasi saat penanaman ditentukan sedemikian rupa sehingga penanaman dapat dilakukan pada saat musim hujan. Jarak yang terlampau lama antara akhir pengolahan dengan penanaman dapat memadat kembali. Saat pengolahan tanah pada umumnya dilakukan pada akhir musim kemarau sehingga dapat segera ditanami pada saat awal musim hujan.

\section{Pengolahan tanah dan penanaman.}

Pengolahan tanah bertujuan untuk mempersiapkan media tumbuh optimum bagi tanaman. Pengolahan tanah secara baik menyangkut pengertian yaitu membersihkan tanah dari tumbuh-tumbuhan pengganggu, menjamin perkembangan sistem perakaran yang sempurna, menjamin peningkatan aviabilitas zat-zat, memperbaiki aerasi dan kelembaban tanah, memeperbaiki kelestarian serta kesuburan tanah dan persediaan air

\section{Penggembalaan}

Dapat mulai dilakukan saat tanaman telah menutup tanah dengan baik dan cukup tahan terhadap injakan dan senggutan. Lama penggembalaan tergantung pada jenis tanaman yang ditanam, tetapi sebagai pegangan umum bagi hijauan yaitu kurang lebih 5 sampai 6 bulan.

\section{Pemeliharaan}

Pastura dibiarkan selama 12 bulan agar spesiesnya betul-betul establish. Pada waktu ini, pembersihan terhadap weed mungkin perlu dilakukan untuk spesiesspesies yang lambat establishnya. Jika pertumbuhan tidak merata, maka dapat dilakukan "slashing" atau memapasi ternak dalam waktu singkat untuk meratakan pertumbuhan. Pada bulan pertama setelah penanaman mungkin perlu dilakukan penyulaman terhadap spesies yang tidak mau tumbuh, sehingga keseimbangan rumput dengan legum sesuai dengan yang dikehendaki. Pemeliharaan yang baik, pastura mampu tahan berproduksi 5 sampai 6 tahun.

Pemotongan dapat dilakukan dengan cara bergilir atau sistem rotasi. Sistem ini biasanya dilakukan dengan cara membagi-bagi padang penanaman menjadi petak-petak (paddock). Sesuai dengan maksud peternak sehubungan dengan jumlah ternak yang digembalakan, pertumbuhan hijauan serta kelebatannya. Penggembalaan berat (over grazing) dan defoliasi yang terlalu ringan (under grazing) harus dihindarkan, karena keduanya akan merugikan. Penggembalaan rendah dapat mengakibatkan produksi berikutnya rendah, pertumbuhan kembali lemah, banyak tumbuh rumput liar dan bahkan bisa menimbulkan erosi tanah. Sedangkan under grazing (defoliasi yang terlalu ringan) 
dapat mengakibatkan hijauan menjadi terlalu tua, serat kasar tinggi, dan kurang palatable dan nilai gizinya sangat rendah (Anonimus, 1985).

\section{Pemupukan}

Merupakan cara yang bertujuan untuk menyelidiki tentang zat-zat apakah yang perlu diberikan kepada tanah sehubungan dengan kekurangan zat-zat tersebut yang terkandung didalam tanah yang yang terkandung didalam tanah yang berguna untuk pertumbuhan dan perkembangan tanaman dalam rangka produksinya agar tercapai hasil yang maksimal. Didalam perlakuanperlakuan yang harus dilakukan terlebih dulu sebelum zat-zat itu diberikan atau ditambahkan kedalam tanah maka perlu dilakukan penyelidikan tentang zat yang kurang apa, berapa besarnya kekurangan itu bagaimana perbandingannya dan kapan waktu pemberiannya, kemudian perlu diselidiki tentang pengaruh yang tidak langsung atau pengaruh apa yang timbul pada bagian-bagian atau sifat-sifat tanah serta tanamantanaman yang dibudidayakan sehubungan dengan pemberian zat-zat tersebut kedalam tanah. Perlakuan tersebut sangat penting dalam pemupukan (Sutejo dan Kartasapoetra, 1988).

\section{Jenis-Jenis Pupuk}

Pengembalian sisa-sisa tanaman dari musim panen pada tanah sebelum musim tanah berikutnya ataupun yang didapat dari sumber lain sedapat mungkin harus dipadukan. Dengan kegiatan pengolahan tanah yang dilakukan. Dengan teknik pembenaman sisa-sisa tanaman akan cepat terombak, melalui pelapukan dan peranan jasad renik, akan kembali menjadi bahan organik tanah. Sisa-sisa atau separuh tanaman, limbah atau kotoran hewan disebut pupuk alam atau pupuk organik. Demikian juga halnya kompos yang dapat diubah dalam tanah menjadi bahan-bahan organik tanah juga disebut pupuk organik. Sedangkan pupuk yang dibuat dipabrik disebut pupuk buatan atau pupuk anorganik. Berdasarkan kandungan unsur haranya dibagi menjadi 2 yaitu pupuk tunggal dan pupuk majemuk. Pupuk tunggal yaitu pupuk yang hanya mengandung 1 macam unsur hara misalnya urea hanya mengandung $\mathrm{N} 2 \mathrm{~K}$ hanya mempunyai kandungan $\mathrm{K}$ sedangkan TSP mempunyai kandungan P. Kemudian pupuk majemuk yaitu pupuk yang mengandung lebih dari 1 macam unsur hara misalnya DAP mempunyai kandungan $\mathrm{N}$ dan $\mathrm{P}$ dan Rustica yellow mengandung N, P dan K (Sutejo danKartasapoetra, 1988). Klasifikasi pupuk berdasarkan pembuatannya ada dua yaitu pupuk alam dan pupuk buatan. Pupuk alam seperti pupuk kandang, hijau, kompos, sedangkan pupuk buatan seperti urea, TSP, KCL, ZA. Pupuk kandang mempunyai kemampuan mengubah berbagai faktor dalam tanah sehingga menjadi faktor-faktor yang menjamin kesuburan tanah. Pupuk kandang dibedakan menjadi dua yaitu pupuk kandang segar, biasanya merupakan kotoran-kotoran hewan yang baru diturunkan oleh hewannya yang kadang-kadang tercampur pula oleh urine dan sisa-sisa makanan dikandang. Kemudian pupuk kandang busuk, biasanya merupakan pupuk kandang yang telah disimpan atau digundukan sehingga mengalami pembusukan. Pupuk hijau, pupuk hijau adalah tanaman atau bagian-bagian tanaman yang masih muda terutama yang termasuk famili leguminosa, yang dibenamkan kedalam tanah dengan maksud agar dapat meningkatkan tersedianya bahan-bahan organik dan unsur-unsur hara bagi pertumbuhan dan perkembangan tanaman. Pupuk kompos merupakan pupuk yang dibuat dengan cara menumpukkan bahanbahan yang mempunyai perbandingan $\mathrm{C} / \mathrm{N}$ yang rendah sebelum digunakan menjadi pupuk. Pupuk kompos juga merupakan zat akhir suatu proses fermentasi tumpukan sampah atau sisa-sisa tanaman (Sutejo dan Kartasapoetra, 1988).

Pupuk buatan memiliki sifat-sifat yang sangat penting seperti urea terdiri dari $45 \% \mathrm{~N}, \mathrm{~N}$ yang paling murah, mudah larut, cepat bereaksi, mudah tercuci bersifat agak asam : 0,5 kg kapur diperlukan untuk menetralisir $1 \mathrm{~kg}$ urea. Amonium sulfat, ZA terdiri dari $21 \% \mathrm{~N}$, bereaksi sedang, cepat, bersifat asam: 0,6 kg kapur diperlukan untuk menetralisir $1 \mathrm{~kg}$ amonium sulfat. Calcium amonium nitrat, CAN terdiri dari $27 \% \mathrm{~N}$, larut dalam air dan mudah tersedia serta mudah tercuci (kombinasi antara calcium carbonat dan amonium nitrat). Potasium chlorida terdiri dari $40-60 \% \mathrm{~K} 2 \mathrm{O}$, mudah larut, bereaksi cepat dan agak mudah tercuci. Potasium nitrat terdiri dari 14\% N, 45\% K2O, mudah larut dan bereaksi cepat. TSP terdiri dari 45\% $\mathrm{P}_{2} \mathrm{O}_{5}$, larut dalam air, bereaksi cepat dan tidak mudah tercuci (Sutejo dan Kartasapoetra, 1988).

\section{Metode Pemupukan}

Metode pemupukan dapat dilakukan sebagai berikut. Penyebaran pupuk, biasanya pupuk yang tidak larut dalam air dan yang bagian-bagian utamanya terikat secara kimiawi, disebarkan secara merata, dilakukan setelah atau sebelum pengolahan tanah dan selanjutnya dibenamkan. Penyemprotan, penyemprotan hanya dapat dilakukan dengan pupuk yang mudah larut dalam air dan tujuannya agar unsur-unsur yang terkandung dalam pupuk, daun-daunan dan batang tanaman pun dapat melakukannya. Side dressed placement/top dressed, pupuk ini ditempatkan diatas permukaan tanah disekitar tempat tumbuh tanaman biasanya dalam menempatkan pupuk diatas permukaan tempat tumbuh tanaman atau disisi tanaman, tanahnya dikorek sedikit agar penempatan pupuk berlangsung dengan baik kemudian ditutup agar tidak tertutup atau terangkut oleh air hujan, pemupukan sebaiknya dilakukan menjelang musim hujan dan minggu pertama sesudah musim penghujan maka pencucian atau pengangkutan oleh air dapat dihindari. In the row placement, yaitu dengan cara menempatkan pupuk pada lubang-lubang benih akan ditanam. Side band placement, yaitu dengan cara pupuk ditempatkan pada tanah selain benih atau tanaman. Pada sisi yang satu atau pada kedua belah sisinya dengan jarak masing-masing $5-7,5 \mathrm{~cm}$ dari tempat benih atau tempat tumbuh tanaman dan dalamnya sekitar 2,5-5 $\mathrm{cm}$ dari permukaan tanah. Plow sole placement, dilakukan pada saat pengolahan tanah 
dengan menempatkan pupuk yang diperlukan secara langsung dibelakang pembajaknya. Dengan cara ini pemupukan dapat merata dan terbenam dalam tanah. dan biasanya pupuk yang mudah larut (Sutejo dan Kartasapoetra, 1988)

\section{Faktor-Faktor Yang Mempengaruhi Produktivi- tas dan Nilai Gizi Tanaman.}

Reksohadiprodjo (1985) menyatakan bahwa faktorfaktor yang mempengaruhi hasil pastura adalah tanah dan spesies.

\section{Tanah}

Setyati (1983) mengemukakan bahwa ada 3 fungsi primer tanah dalam mendukung pertumbuhan tanaman yaitu, memberikan unsur mineral, sebagai tempat cadangan makanan dan sebagai tempat bertumpu untuk tegak. Dikatakan lebih lanjuk bahwa faktor lain yang berpengaruh terhadap kesuburan tanah adalah tingkatan bentuk hara yang tersedia bagi tanaman. Tingkatan tersebut tergantung banyak faktor diantaranya adalah kelarutan zat hara, PH, kapasitas pertukaran kalori (KPK), tekstur tanah dan jumlah zat organiknya.

\section{Spesies}

Kemampuan suatu tanaman untuk menyesuaiakan diri dengan lingkungannya dari faktor genetik berpengaruh pada proses pertumbuhan dan produksi suatu tanaman. Disini dapat dikemukakan suatu contoh bahwa familia gramineae (Rumput-rumputan) mempunyai pembawaan yang berbeda dibandingkan dengan tanaman dai familia leguminoceae (Whiteman, 1980).

\section{Faktor-faktor yang mempengaruhi padang penggembalaan}

Menurut Susetyo et. al. (1981), faktor-faktor yang mempengaruhi padang penggembalaan adalah sebagai berikut :

\section{Air}

Air yang terbatas mempengaruhi fotosintesis dan perluasan daun karena tekanan air mempengaruhi pembukaan stomata perluasan sel (Setyati, 1991). Air berfungsi untuk fotosintesis, penguapan, pelarut zat hara dari atas ke daun. Jika ketersediaan air terpenuhi maka seluruh proses metabolisme tubuh berlangsung, berakibat produksi tanaman tinggi (Anonimus, 1990).

\section{Intensitas Sinar}

Intensitas sinar di bawah pohon atau tanaman pertanian tergantung pada bermacam-macam tanaman, umur, dan jarak tanam, selain waktu penyinaran. Keadaan musim dan cuaca juga berpengaruh terhadap intensitas sinar yang jatuh pada tanaman selain yang ada di bawah tanaman utama (Susetyo et al., 1981). Menurut Crowder and Chedda (1982) bahwa peningkatan pertumbuhan tanaman sejalan dengan peningkatan intensitas cahaya. Jumlah energi matahari yang diterima seawal mungkin pada saat munculnya sampai periode pemasakan adalah penting untuk akumulasi berat kering selama periode tersebut.

\section{Kompetisi zat-zat makanan}

Kompetisi terjadi antara "Companion Crop" dengan tanaman utama. Kompetisi ini akan nampak jelas pada daerah-daerah yang kekurangan air atau di waktuwaktu musim kering. Kesulitan ini dapat diatasi dengan menanam tanaman lain yang berbeda kebutuhan zatzat makanan seperti nitrogen (Susetyo et al., 1981).

\section{Kekompakan tanah}

Pastura yang digembala dengan stocking rate yang tinggi (8 sampai 10 ekor/ha) akan menyebabkan tanah menjadi kompak, padat dan berakibat mengurangi aerasi akar dan daya tembus air (Susetyo et al., 1981). Menurut Anonimus (1990), tanah berhubungan dengan unsur-unsur hara yang terkandung di dalamnya. Unsurunsur N, P, K diperlukan tanaman dalam jumlah relatif besar. Jika kandungan ini cukup besar dan seimbang dalam tanah maka akan mendukung tercapainya produksi pangan dalam jumlah besar.

\section{Inokulasi}

Untuk beberapa jenis legum tidak akan tumbuh dan berproduksi optimal kalau tidak diberikan inokulum yang khusus terutama terjadi pada tempat-tempat yang belum pernah ditanami legum (Susetyo et al., 1981).

\section{Temperatur}

Menurut Anonimus (1990), tanaman memerlukan temperatur yang optimum agar dapat melakukan aktivitas fotosintesis dengan baik, sedangkan pengaruh temperatur terhadap perluasan daun akan mempengaruhi pertumbuhan tanaman secara keseluruhan. Temperatur tanah berpengaruh terhadap proses biokimia dimana terjadi pelepasan nutrien tanaman atau memproduksi toksik bagi tanaman, dan berpengaruh juga terhadap kecepatan absorbsi air dan nutrien (Setyati, 1983). Jadi hanya tanaman yang dapat menyesuaikan dengan temperatur lingkungan yang akan tumbuh sehingga menghasilkan produksi tinggi.

\section{Angin.}

Pengaruh angin tergantung dari kelembaban dan kecepatan angin. Angin dapat merusak tanaman dan mengurangi fotosintesis serta menyebarkan bakteri penyebar penyakit pada daun. Angin yang kering menyebabkan pengeringan daun dan merusak daundaun tersebut secara mekanis (Crowder and Chedda, 1982).

\section{Curah Hujan}

Merupakan salah satu faktor penting yang mempengaruhi pertumbuhan dan produksi bahan kering di daerah tropik dan subtropik (Crowder and Chedda, 1982).

\section{Jenis Rumput Padang Penggembalaan}

\section{Rumput BD (Brachiaria Decumbens)}

Brachiaria decumbens atau yang lebih dikenal rumput $\mathrm{BD}$, rumput signal merupakan rumput pakan temak jenis unggul disamping jenis rumput lainnya . Rumput ini berasal dari daerah Uganda, Afrika . Rumput bede termasuk rumput berumur panjang, dapat tumbuh dengan membentuk hamparan lebat dan penyebarannya sangat cepat melalui stolon . Rumput bede berdaun kaku, pendek, berbulu halus, warna hijau gelap dan berstruktur agak kasar . Rumput bede tahan penggembalaan berat, tahan injakan dan renggutan serta tahan kekeringan dan responsif 
terhadap pemupukan nitrogen. Selain itu rumput ini juga cepat tumbuh dan berkembang sehingga mudah menutup tanah, tetapi tidak tahan terhadap genangan air. Rumput ini merupakan bahan hay yang balk, karena batangnya kecil mudah menjadi kering. Rumput bede dapat tumbuh baik pada ketinggian 0-1200 m (dataran rendah sampai dataran tinggi) dengan curah hujan 762$1500 \mathrm{~mm} /$ tahun, kemasaman tanah (pH) 6-7 (Kismono dan Susetyo, 1977).

\section{Star Grass}

Rumput Stargrass /Rumput Bermuda awalnya berasal dari savana Afrika dan merupakan nama umum untuk semua spesies Afrika Timur Cynodon. Tumbuh di daerah terbuka seperti padang penggembalaan Meskipun sebagian besar spesies ini tetap di Afrika, saat ini Rumput Stargrass ditemukan di iklim hangat di seluruh dunia antara $45^{\circ}$ dan $45^{\circ}$ selatan lintang utara. Hal ini dapat ditemukan tumbuh di padang rumput dan hutan terbuka. Rumput ini dikenal juga sebagai rumput bermuda di Amerika Serikat karena sudah diperkenalkan dari Pulau Bermuda.

Rumput Stargrass adalah rumput merayap, dan akan merayap di sepanjang tanah. Rumput ini memiliki sistem akar yang mendalam, dan dalam situasi kekeringan sistem akar dapat tumbuh 47-59 inci (120$150 \mathrm{~cm}$ ) mendalam. Sebagian besar massa akar terletak 24 inci $(60 \mathrm{~cm})$ di bawah permukaan. Rumput Stargrass dapat tumbuh di tanah yang kualitasnya buruk. Selama kekeringan bagian atasnya akan mati, tetapi rumput akan terus tumbuh dari rimpang nya. Rumput ini sangat mudah tumbuh pada iklim lembab dan hangat, dengan curah hujan 16 inci $(410 \mathrm{~mm})$ per tahun.

Rumput Stargrass adalah rumput suksesi awal, dan pertama yang tumbuh kembali setelah kebakaran rumput, yang membakar cukup sering di savana Afrika. Rumput Bermuda dulu dianggap sebagai gulma yang sangat invasif dan kompetitif. Namun, pada saat ini rumput star grass menyelamatkan ribuan hektar tanah pertanian dari erosi. Rumput star grass sangat tepat di kombinasikan dengan hijauan untuk pakan ternak di padang penggembalaan

\section{Leguminosa}

Leguminosa mempunyai peranan yang sangat penting di dalam meningkatkan produktivitas pastura dikarenakan kemampuan mereka dalam memfiksasi sejumlah nitrogen di udara. Kontribusi langsungnya terhadap produktivitas ternak melalui penyediaan sumber pakan yang kaya akan nitrogen. Selain itu, leguminosa dapat meningkatkan produktiivitas rumput melalui peningkatan penyerapan nitrogen tanah oleh rumput apabila leguminosa ditanam bersamaan dengan rerumputan. Namun di Indonesia pola penamanan campuran ini belum banyak diaplikasikan di dalam usaha ternak ruminansia. Informasi tentang budidaya pertanamaan campuran terutama mengenai perbandingan populasi antara populasi rumput dan leguminosa yang biasa tumbuh di Indonesia dan pengaruhnya terhadap produksi dan kulitasnya belum banyak dipublikasi

\section{KESIMPULAN DAN SARAN}

\section{Kesimpulan}

Peternakan menggunakan sistem padang penggembalaan yang baik dan sesuai dengan teknis penanamam yang baik akan sangat bermanfaat untuk efisiensi tenaga kerja yang digunakan, karena proses pemeliharaan tidk menuntut tenaga yang banyak di lapangan serta. Selain itu dan efektifitasbeterak tercapai. Hal ini berkaitan dengan nilai ekonomi untuk poses produksi. Metoda pastura yang dilakukan akan sangat mengurangi pengeluaran untuk pakan ternak. Sampai saat ini biaya yang dikeluarkan untuk pemeliharaan ternak hampir $2 / 3$ dari biaya produksi yang bersumber dari penyedian pakan hijauan. Sistem penggembalaan (Pastura) mampu meningkatkan pertumbuhan bobot badan dengan kisaran 0,5 s.d o,6 kg/hari tanpa pemberian pakan tambahan lainnya.

Pemeliharaan ternak sapi dengan metoda pastura mampu mengefisienkan tenaga kerja, namun pengawasan terhadap ternak harus lebih ekstra karena ternak akan lebih rentan terhadap cedera fisik dan juga rentan terhadap penyebaran penyakit baik ekstoparasit maupun endoparasit.

\section{UCAPAN TERIMA KASIH}

Kepada Bapak Ir. Sugiono, M.P (Kepala BPTUHPT Padang Mengatas), Sdr. Rifqi Elfajri, S.Pt (Pengawas Bibit Ternak Ahli), Tim Pengawas Mutu Pakan BPTUHPT Padang Mengatas dan semua pihak yang telah membantu dalam pembuatan artikel ini, maka penulis ucapan terima kasih.

\section{DAFTAR PUSTAKA}

Anonymous.1990. Usaha Peternakan, Perencanaan Usaha, Analisis dan Pengelolaan. Direktorat Bina Usaha Petani Ternak dan Pengelolaan Hasil Peternakan.

Anonim. 2002. Rekalkulasi Penutupan Lahan Pada Kawasan Hutan dan Areal Penggunaan Lain. Departemen Kehutanan Republik Indonesia, Jakarta.

Crowder L V and Chedda H R 1982 Tropical Grassland Husbandry. Longman Inc. New York.

Kismono, I . dan S . Susetyo . 1977 . Pengenalan Jenis Hijaun Tropika Penting Produksi Hijauan Makanan Ternak Untuk Sapi Perah . BPLPP . Lembang, Bandung.

Reksohadiprodjo, S. 1985. Produksi Tanaman Hijauan Makanan Ternak Tropika. BPFE, Yogyakarta.

Kismono, I . dan S . Susetyo . 1977 . Pengenalan Jenis Hijaun Tropika Penting Produksi Hijauan Makanan Ternak Untuk Sapi Perah . BPLPP . Lembang, Bandung.

Setyati. 1983. Pengantar Agronomi. Cetakan ke -4. PT. Gramedia, Jakarta.

Susetyo. 1981. Hijauan Makanan Ternak. Direktorat Departemen Pertanian. Jakarta.

Sutedjo, M. M., dan A. G. Kartasapoetra. 1988. Pengantar Ilmu Tanah. terbentuknya Tanah dan Tanah Pertanian. Bina Aksara. Jakarta.

Whiteman P. C., 1980. Tropical Pasture Science. Ed. Oxford University Press, New York 